\title{
X-ray micro computed tomography characterization of porosity in Rotliegend sandstones on the northern slope of the Wolsztyn Ridge, western Poland
}

\author{
Anna POSZYTEK ${ }^{1, *}$, Zbigniew MIKOŁAJEWSKI ${ }^{2}$ and Marek DOHNALIK ${ }^{3}$ \\ 1 University of Warsaw, Faculty of Geology, Institute of Geochemistry, Mineralogy and Petrology, Żwirki i Wigury 93, \\ 02-089 Warszawa, Poland \\ 2 Polish Oil and Gas Company (PGNiG S.A.), Exploration and Production Branch, Piła, pl. Staszica 9, 64-920 Piła, Poland \\ 3 Oil and Gas Institute - National Research Institute, Well Logging Department, Lubicz 25a, 31-503 Kraków, Poland
}

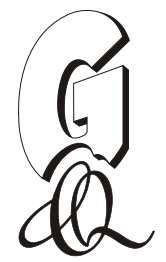

\begin{abstract}
Poszytek, A., Mikołajewski, Z., Dohnalik, M., 2016. X-ray micro computed tomography characterization of porosity in Rotliegend sandstones on the northern slope of the Wolsztyn Ridge, western Poland. Geological Quarterly, 60 (4): 801-810, doi: $10.7306 / g q .1314$

Natural gas in the Polish Rotliegend Basin occurs in porous and permeable aeolian sandstones, and traps are mostly structural. Lithological traps are rare and occur on the northern slope of the Wolsztyn Ridge where fluvial and aeolian sandstones overlap with alluvial facies. Both fluvial and aeolian sandstones are reservoir rocks in this area. The X-ray micro computed tomography (MCT) results and microscopic observations indicate that the sandstones in lithologic traps on the northern slope of the Wolsztyn Ridge form highly compartmentalized vertical reservoir rocks composed of four types of sandstones. The profiles are dominated by very low-porosity fluvial sandstones (F2), and low-porosity aeolian and fluvial sandstones (A2, F1). The A1 type of sandstones with high porosity $(10 \%)$ occurs only in some sections of the profiles. The most important diagenetic processes that reduced porosity were compaction and cementation by carbonate cements. All studied sandstones were subjected to the same diagenetic processes. However, each of the processes ran with varying intensity in different types of sandstones. Detailed analyses of pore distribution by MCT methods with respect to primary depositional or lithofacies effects, and secondary diagenetic effects, help to understand the 3D geometry of pores and pore shape-size distributions. The results can be used in the studies of other sandstones with a different origin and age.
\end{abstract}

Key words: Rotliegend, lithologic traps, sandstones, porosity, Wolsztyn Ridge, computed microtomography.

\section{INTRODUCTION}

The Upper Rotliegend succession has been a target for natural gas exploration in western Poland for over fifty years (Fig. 1; P. Karnkowski, 1999; Karnkowski, 1999; Wolnowski, 2004), and aeolian sandstones are the most important reservoir rocks (Karnkowski, 2007; Kiersnowski et al., 2010a). In the Poznań Basin (Fig. 1), aeolian sandstones have porosity $>20 \%$ and permeability >1000 mD over a wide area (Buniak et al., 2009; Papiernik et al., 2010; Such et al., 2000, 2010). Most natural gas accumulations in the Poznań Basin occur in structural traps (Karnkowski, 1999). Previous studies have indicated that a decrease in the sandstones' porosity and permeability occurs in the south of the basin and is linked with the occurrence of fluvial and alluvial deposits near the Wolsztyn Ridge (Buniak et al., 2009). However, combination (lithological-structural) traps occur on the northern margin of the Wolsztyn Ridge, for example at the Ujazd and

\footnotetext{
* Corresponding author, e-mail: anna.poszytek@uw.edu.pl
}

Received: April 28, 2016; accepted: August 22, 2016; first published online: September 26, 2016
Paproć gas fields (Kwolek et al., 2004), where reservoir rocks include both aeolian and fluvial sandstones. No detailed studies of the porosity distribution in aeolian and fluvial sandstones on the northern margin of the Wolsztyn Ridge have so far been published. The aim of this study was therefore to investigate the porosity within these sandstones using microscopy observation and modern analyses as computed microtomography. Qualitative and semi-quantitative analyses of computed microtomography with respect to primary depositional or lithofacies effects, and secondary diagenetic effects, help to understand the porosity distribution in tested lithological traps.

\section{GEOLOGICAL SETTING}

The Southern Permian Basin in western and central Europe extends from Great Britain to Poland and contains important reserves of natural gas derived from Carboniferous shale and coal source rocks (Glennie, 1990; Ziegler, 1990; Karnkowski, 1999; Doornenbal and Stevenson, 2010). The South Permian Basin system is divided into a number of smaller basins, including the Polish Permian Basin (Fig. 1A) which developed as a result of post-Variscan dextral transtension (Nikishin et al., 2002; Lamarche and Scheck-Wenderoth, 2005). 


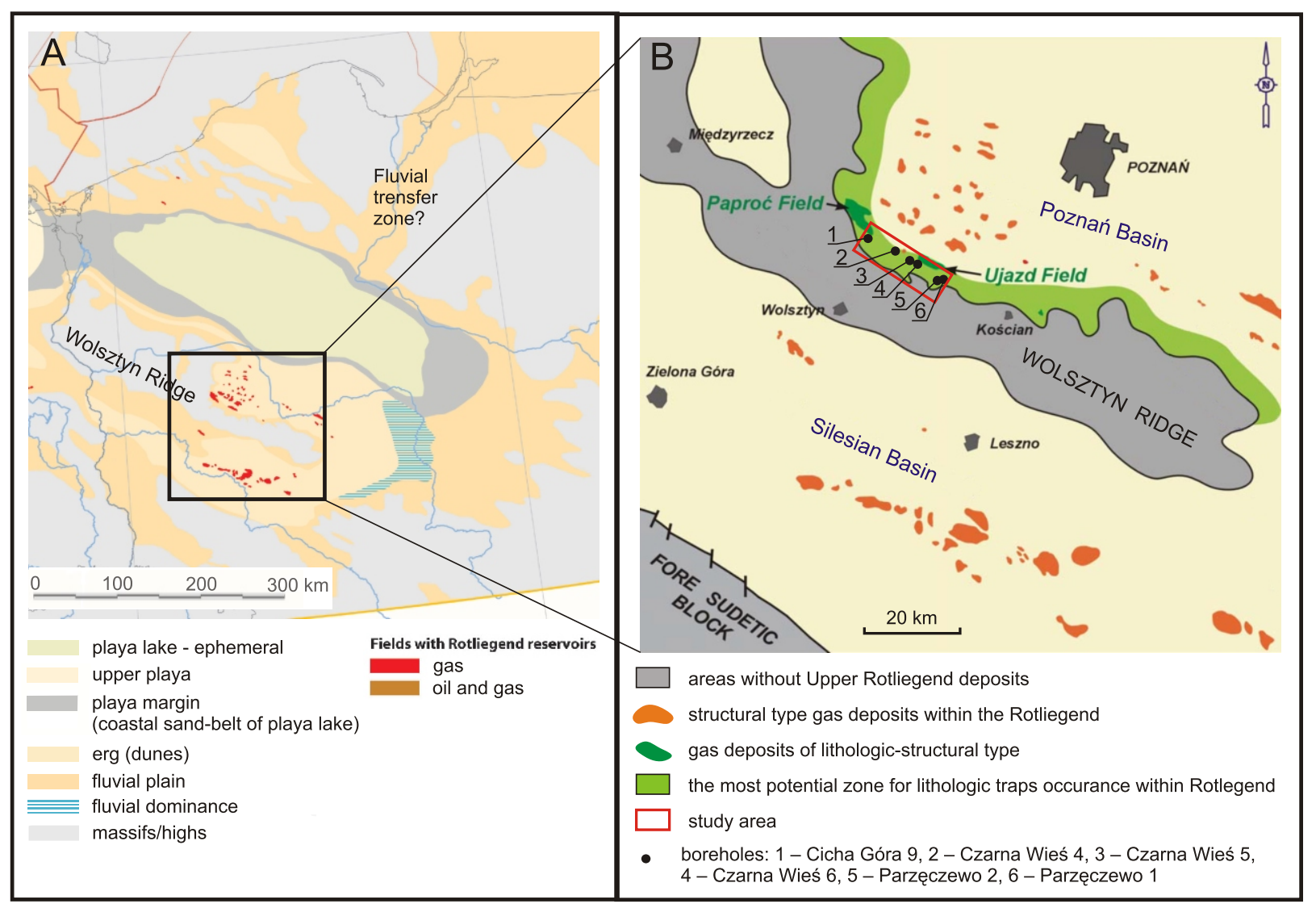

Fig. 1. Location map of the gas fields within the top part of the Upper Rotliegend deposits in the Polish Permian Basin

A - after Kiersnowski in Doornenbal and Stevenson (2010); B - after Kwolek et al. (2004)

In the Polish Permian Basin, Lower Rotliegend (Autunian) sedimentary and volcanic rocks are overlain by Upper Rotliegend rocks deposited under arid and semi-arid climatic conditions (e.g., Karnkowski, 1999; Kiersnowski et al., 2010b; Kiersnowski, 2013). Continental Rotliegend sedimentation was terminated by the Zechstein marine transgression and by Kupferschiefer sedimentation (e.g., Jerzykiewicz et al., 1976; Peryt, 1976; Nemec and Porębski, 1977; Karnkowski, 1986; Kiersnowski, 1997; Wagner and Peryt, 1997; Michalik, 2001; cf. Peryt et al., 2012). The Kupferschiefer (T1) is overlain by the Zechstein Limestone (Ca1) and then PZ1 evaporites (Dyjaczyński and Peryt, 2014).

Distribution of the Upper Rotliegend sedimentary deposits, their facies and thickness were controlled by the Wolsztyn Ridge. The Wolsztyn Ridge is a tectonic horst which divides the southern section of the Polish Rotliegend Basin into the Poznan sub-basin to the north, and the southern Silesian sub-basin (Fig. 1B). The ridge is composed of folded, faulted and eroded Visean to Namurian flysch type rocks capped by a thick cover of Upper Carboniferous-Lower Permian volcanic rocks (Mazur et al., 2003, 2006; Dadlez, 2006; Geisler et al., 2008; Kiersnowski et al., 2010b). Wolsztyn Ridge was the source area for alluvial and fluvial sediments during the sedimentation of the Upper Rotliegend (Karnkowski, 1987, 1994; Weihe, 1997; Kiersnowski et al., 2010b). Close to the Wolsztyn Ridge, several sedimentary cycles of prograding alluvial fans and fluvial deposition can be distinguished (Kiersnowski et al., 2010b). These deposits are frequently interbedded with aeolian sands (Fig. 2).

The Poznań Basin, located in the central part of the Polish Rotliegend Basin, is characterized by large thicknesses of the Upper Rotliegend, exceeding $1 \mathrm{~km}$. The Upper Rotliegend section is composed of alluvial and fluvial rocks with a considerable proportion of aeolian sandstones in the central part of the Poznań Basin. Aeolian sandstones are the main reservoir rocks for gas accumulation (Jarzyna et al., 2009; Papiernik et al., 2010; Poszytek, 2014). The reservoir properties of aeolian sandstones are characterized by very good porosity $(>20 \%)$ and permeability (>1000 mD) and form a wide zone in the central part of the basin. Previous studies (Buniak et al., 2009) indicated that the decrease in the porosity and permeability values of aeolian sandstones to the south and north in the Poznan Basin is linked with the occurrence of fluvial deposits near the Wolsztyn Ridge or with the greater subsidence, which is in turn associated with more intense compaction of aeolian sandstones.

Numerous conventional gas reservoirs have been recognized in Poland (Fig. 1) within the porous and permeable aeolian sandstones of the Noteć Formation sealed by Zechstein evaporites and impermeable claystones (e.g., Kwolek et al., 2004; Wolnowski, 2004; Karnkowski, 2007; Kiersnowski et al., $2010 a, b)$. Huge amount of geological information from many oil boreholes resulted in number of publications dedicated on 


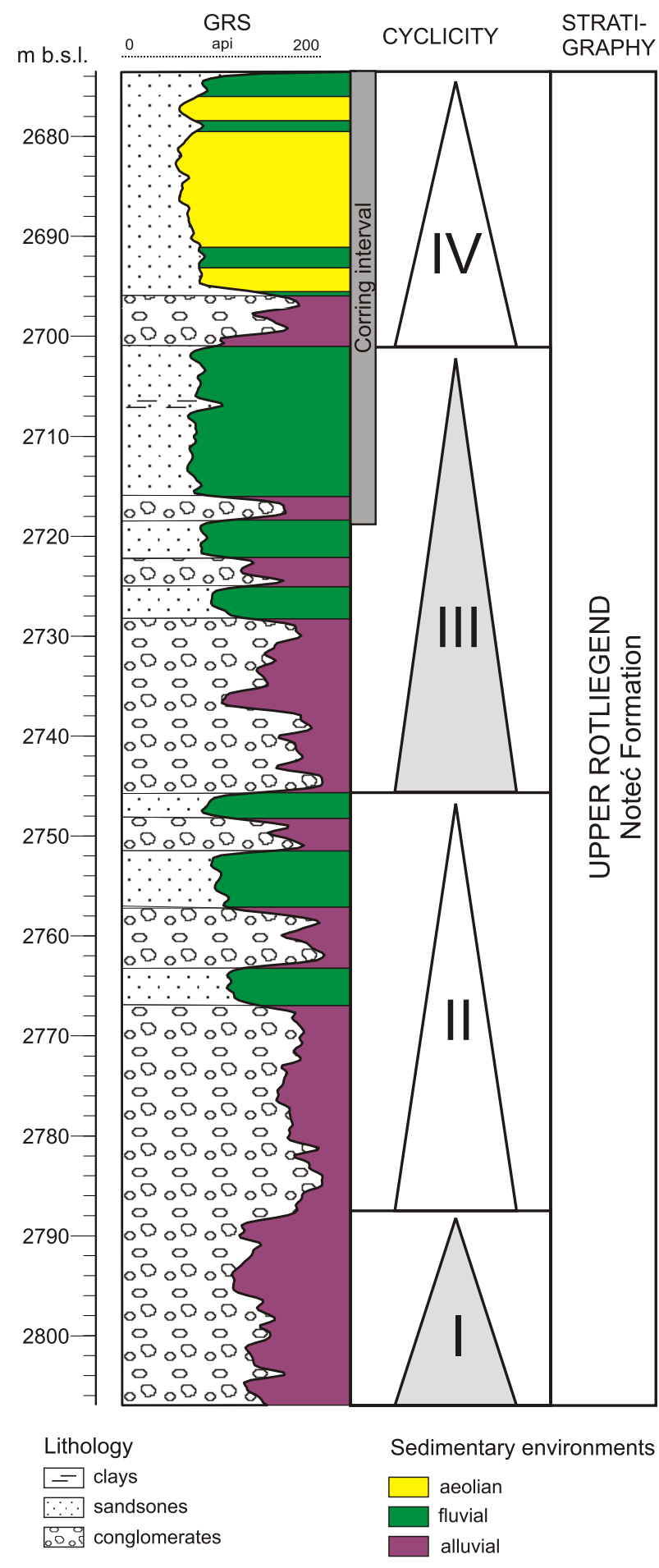

Fig. 2. Upper Rotliegend lithofacies in the Cicha Góra-9 borehole located close to the Wolsztyn Ridge, cyclic deposition interpreted based on Kiersnowski et al. (2010b)

Rotliegend sedimentation (Karnkowski, 1987, 1994; Kiersnowski, 1997; Buniak et al., 1999; Pokorski and Kiersnowski, 1999; Szwarc and Kiersnowski, 1999; Kiersnowski and Buniak, 2006; Kiersnowski et al., 2010b), its petrography (Rochewicz, 1980; Muszyński and Rydzewska, 1986; Maliszewska and Kuberska, 1996; Gregosiewicz and Protas, 1997), reservoir properties and their relationship to lithofacies (Such, 1996;
Such et al., 2000; Buniak et al., 2009), and exploration of tight gas (Poprawa and Kiersnowski, 2008, 2010; Such et al., 2010).

Lithological and structural traps occur on the northern margin of the Wolsztyn Ridge (Fig. 1B) at depths between 2,400 and 2,800 m (Fig. 3). Lithological traps are determined by a combination of the extent line of porous, permeable sandstones (aeolian and fluvial) and the seal surface of impermeable clastic deposits of the Rotliegend (Fig. 3; Karnkowski, 1985; Kwolek et al., 2004). Lithological traps with gas deposits on the northern margin of the Wolsztyn Ridge were discovered in the 1970s (Ujazd gas field) and 1980s (Paproć gas field). Natural gas reserves are estimated at 3 billion $\mathrm{m}^{3}$ in the Ujazd gas fields and 4.5 billion $\mathrm{m}^{3}$ in the Paproć gas fields (Karnkowski, 1999). Currently, exploration has been focused on the northern margin of the Wolsztyn Ridge to recognize the existing gas deposits and discover new gas fields (Kwolek et al., 2004). However, there are no detailed publication on the reservoir properties and interpretation of the factors that played a major role in the distribution of reservoir properties.

\section{MATERIALS AND METHODS}

Data for this study came from six boreholes drilled through the last decade (Czarna Wieś 4, Czarna Wieś 5, Czarna Wieś 6, Parzęczewo 1, Parzęczewo 2, Cicha Góra 9) located between the Paproć and Ujazd gas fields. Lithofacies and the depositional environment of the rocks were interpreted during macroscopic observation of cores. Later, 37 samples of aeolian and fluvial sandstones from 2,550-2,700 m depth were collected, based on structural and textural differentiation of rocks; including sandstones, fine- to coarse-grained, fine to poorly sorted, massive, cross bedded and horizontal bedded. Next 37 core plugs $(2 \times 0.5 \mathrm{~cm})$ were prepared for micro computed tomography (MCT). Thin sections were cut from the plugs after computed microtomography analyses and were used for microscope observation.

Microscope analyses investigated the sandstones' composition, grain sorting, grain contacts and the presence of authigenic cements, as well as the occurrence of primary (depositional) and secondary (diagenesis-related) porosity. A scanning electron microscope (JSM6380 LA) was used to investigate the detailed characteristics of the pore system using the ImageJ programme, and binary images were used for qualitative and quantitative pore description.

The pore distribution of the Rotliegend sandstones was also investigated using MCT. X-ray MCT (Van Geet et al., 2001) is a non-destructive technique allowing $3 \mathrm{D}$ visualization of the internal structure of an object (Ketcham and Carlson, 2001; Stock, 2008; Zapalski and Dohnalik, 2013; Couves et al., 2016). Further analysis of a 3D image of a rock sample can provide characterization of the qualitative and quantitative parameters of the pore space (Cnudde et al., 2009; Fusi and Martinez-Martinez, 2013; Agbogun et al., 2013). The MCT results were supported by detailed sample descriptions using an optical microscope and a SEM.

During X-ray MCT analyses, X-ray are attenuated during sample penetration and reach the detector surface where their intensity is converted into an electrical signal which creates a digital image known as a projection. The sample rotates by $360^{\circ}$, and several hundred projections are recorded at different angular positions.

A filtered back-projection algorithm is then used to reconstruct the 3D structure of the object from the projections, and a digital image is produced to illustrate the variability of the linear 


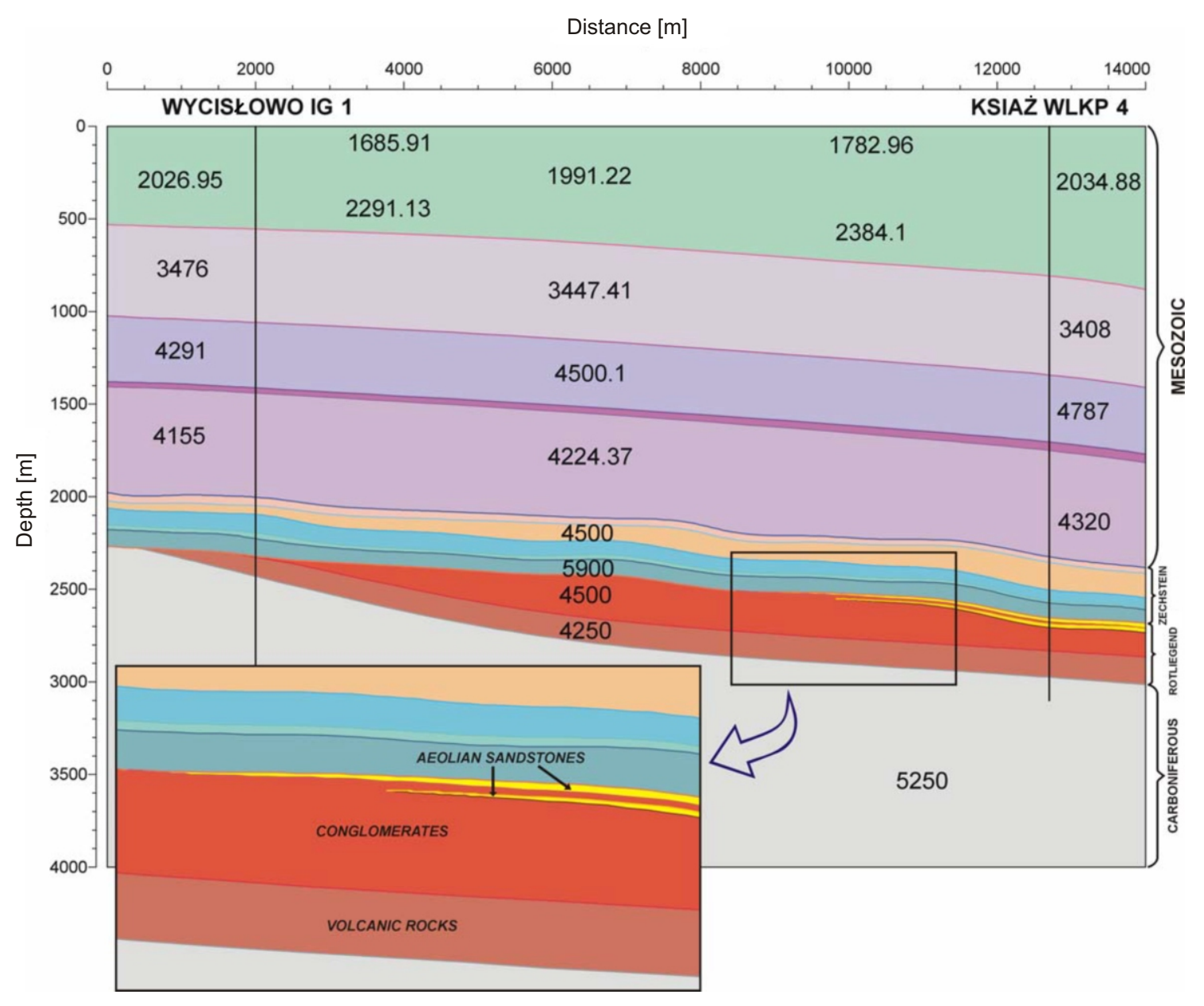

Fig. 3. Velocity model of Mesozoic and Permian deposits in the Wycisłowo-Książ region (NE slope of the Wolsztyn High; Kwolek et al., 2004)

absorption coefficient (Stock, 2008). The image consists of voxels which are the smallest elements of a spatial image and approximately correspond to pixels in $2 \mathrm{D}$ graphics. To calculate the porosity of the rock image, a binarisation process is required; all the voxels representing voids are assigned to one image layer, whereas all other voxels are assigned to a second layer representing the rock matrix. The porosity is calculated as the ratio between the volume of pore-structure voxels to the total volume of the sample.

MCT measurements were made by the Oil and Gas Institute in Cracow using a Benchtop CT160Xi (Nikon) X-ray microtomograph. The X-ray source installed in the apparatus emits a conical beam of $X$-ray with an acceleration voltage in the range of $40-160 \mathrm{kV}$ and up to $3 \mu \mathrm{m}$ resolution (the resolution of the examined samples was $6 \mu \mathrm{m}$ ). The accuracy of the measurements depends on the number of projections, the number of averaging projections at each angular position, as well as the exposition/exposure time. These three parameters may significantly increase the signal-to-noise ratio in the projections registered.

The results of microtomographic studies are presented in the form of 3D visualisations of the pore space. 3D visualisation enables a qualitative analysis of the characteristics of the pore space, including assessment of the anisotropy of the pore network pattern in the sample (Svitelman and Dinariev, 2013).
Charts showing the pore distribution display the quantitative characteristics of each sample and a comparison with other samples. Quantitative evaluation of porosity used MAVI software (Modular Algorithms for Volume Images, Fraunhofer Institute for Industrial Mathematics ITWM).

$3 \mathrm{D}$ visualisation of the pore space used $A V I Z O 6.3$ software (registered trademark, developed by Visualization Sciences Group, now FEI), and the pore network was subdivided into subgroups, each subgroup representing a set of interconnected pores which do not communicate with other subgroups. The subgroups have been divided into classes according to their volume. The unit used to describe volume classes is the voxel, which in this study has the dimensions of $6 \times 6 \times 6 \mu \mathrm{m}$ so 1 voxel $=216 \mu \mathrm{m}^{3}$ and this is the smallest volume which can be diagnosed in this study. Six volume classes were distinguished in the porosity subgroups according to a logarithmic scale, and the subgroups were marked with specific colours:
I. 1-9 voxels - violet,
II. 10-99 voxels - blue,
III. 100-999 voxels - red,
IV. 1000-9999 voxels - green,
V. $10000-99999$ voxels - white,
VI. >100 000 voxels - yellow.

Charts of pore distribution were constructed based on the division of the pore space into subgroups. The charts show the 
percentage distribution of particular volume classes of the pore network, indicating which class dominates in the samples. A dominance by the high pore classes (interconnected pores) results in the rock having better reservoir parameters (Dohnalik et al., 2010; Zalewska and Dohnalik, 2011). Quantitative analyses of the variability of the pore network were based on charts showing the distribution of pore classes.

\section{RESULTS}

\section{DEPOSITIONAL SETTING}

The Rotliegend deposits on the northern margin of the Wolsztyn Ridge are characterized by a wide range of clastic facies. The study profiles consist of thick (up to $100 \mathrm{~m}$ in their lower part) alluvial fan sediments composed of conglomerates, overlain by finer-grained alluvial and fluvial deposits (sandstones and mudstones). These rocks are interbedded with aeolian sandstones. Fluvial sandstones consist of medium- and coarse-grained sandstones which are poorly sorted and cross-bedded, or locally massive, and are interpreted as channel and overbank facies. Aeolian sandstones consist of medium- and fine-grained sandstones with inclined (up to $15^{\circ}$ ) bedding surfaces, interpreted as dune facies. The thickness of the fluvial and aeolian sandstones varies from a few to tens of metres (Fig. 3).

Previous studies (Kiersnowski et al., 2010b) indicated that the alluvial and fluvial deposits with interbeds of aeolian deposits are characterized by rapid changes in sedimentary environment conditions. Alluvial fans represent a syn- or post-tectonic sedimentary response to fault activity. Four sedimentary cycles were distinguished in the study area based on cyclic deposition analyses provided by Kiersnowski et al. (2010b) (Fig. 2). During tectonic quiescence and low activity on the prograding alluvial fan, less coarse fluvial deposits dominated. These deposits are frequently interbedded with aeolian sands as a result of alternating arid and humid climatic periods and due to easier migration of aeolian dunes up the alluvial fan slopes (Kiersnowski et al., 2010b).

\section{MICROSCOPY OBSERVATION}

Tested aeolian sandstones are represented by quartz and sublithic arenites (according to the classification of Pettijohn et al., 1972; Fig. 4). The grains are loosely to densely packed, and the intergranular contacts are point or planar, indicating physical compaction. Grain sorting is good to moderate. Some samples are characterized by a high porosity value $(>10 \%-\mathrm{A} 1$ sandstones). The high porosity was accompanied by low contents of cement which was mainly in the form of clay-hematite grain coatings and rare quartz coatings on quartz grains. Much of the aeolian sandstones were characterized by intense cementation by carbonate (calcite) and clay (illite and kaolinite) cements, which considerably reduced primary porosity (Fig. 5A2 sandstones)

According to the classification of Pettijohn et al. (1972), the fluvial sandstones include lithic, sublithic and subarkosic arenites (Fig. 4). The fluvial granulometry is characterized by poor sorting (Fig. 5). The rock clasts include mainly volcanic rocks from the erosion of the Wolsztyn Ridge. The grains are densely packed, and the intergranular contacts are point or planar, indicating physical compaction. The framework often contains matrix and carbonate cement (Fig. 5), which fill the inter-

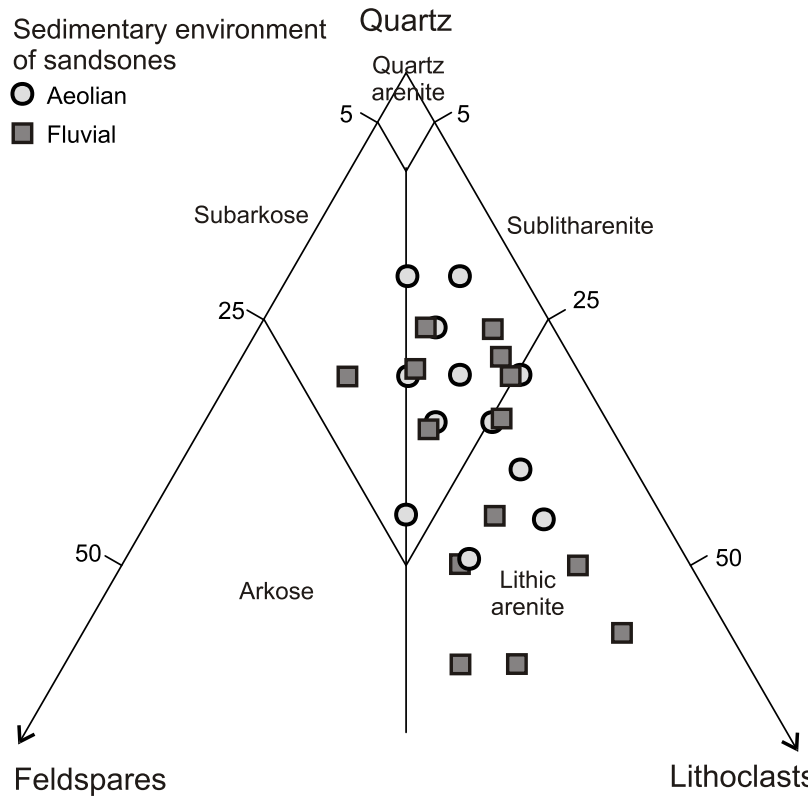

Fig. 4. Mineral composition of the skeletal grains of aeolian and fluvial sandstones in the QFL classification diagram of Pettijohn et al. (1972)

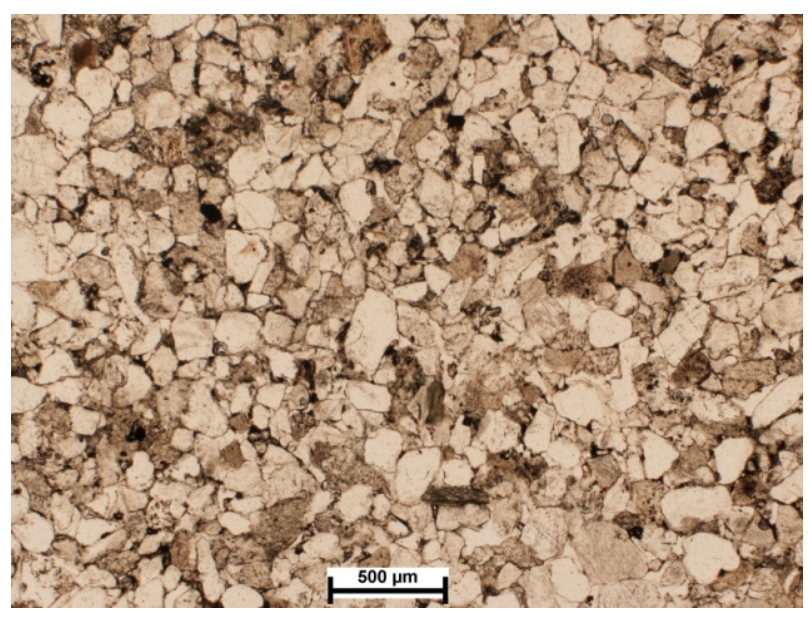

Fig. 5. Variability of lithology in aeolian and fluvial sandstones with respect to the distinguished types of sandstone

granular porosity partly or completely. Fluvial sandstones are characterized by low and very low porosity $(<5 \%-\mathrm{F} 1$ and F2 sandstones). Porosity is both intergranular and intragranular. Intragranular porosity plays a smaller role than intergranular porosity.

Compared to aeolian sandstones, fluvial sandstones are characterized by poorer grain sorting and lower porosity (Figs. 5 and 6).

\section{MICRO COMPUTED TOMOGRAPHY}

Based on qualitative and semi-quantitative analyses of MCT results all samples were divided into four groups, depending on their sedimentary origin and character of porosity. The aeolian sandstones were subdivided into high- (A1) and low-po- 
A1

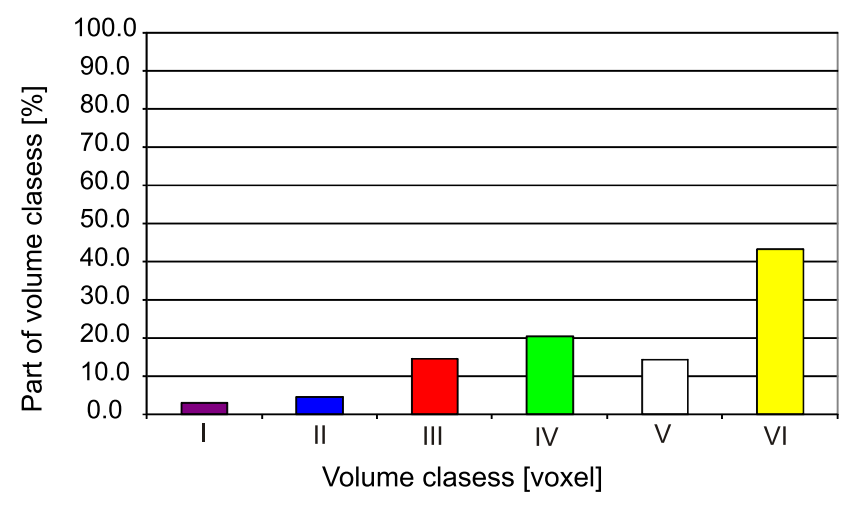

F1

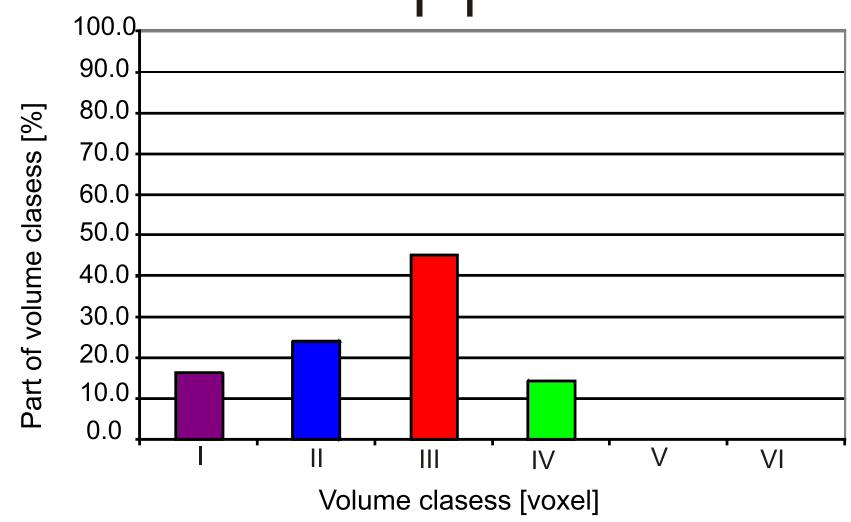

A2

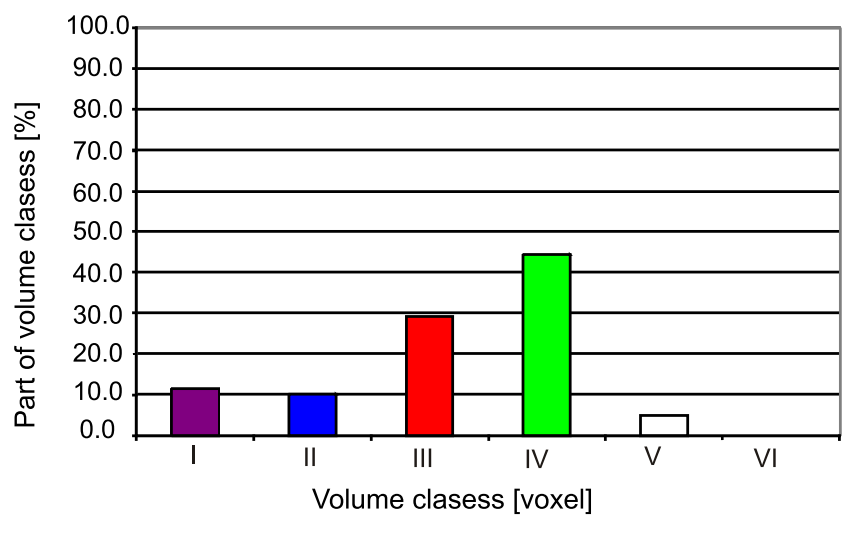

F2

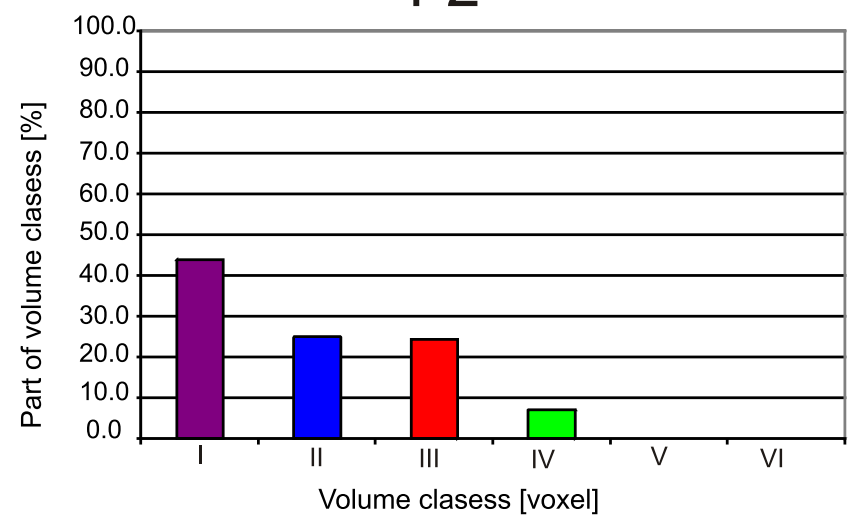

Fig. 6. Variability of the porosity distribution in the distinguished types of sandstones

rosity (A2) facies. Fluvial sandstones can be subdivided into two: low (F1) and very low porosity (F2) (Figs. 5 and 6).

A1 sandstones. A1 sandstones are characterized by welldeveloped primary intergranular porosity (up to 10\%), good grain sorting and low cement content (Fig. 5). Plots of pore volume class distribution are characterized by a low proportion of classes I, II and III relative to the higher classes (Fig. 6). Class $\mathrm{VI}$ pore volume occurs in all samples. It is often dominant or co-occurs with another dominant, class $\mathrm{V}$ pore volume. Class $\mathrm{VI}$ pore volume is related to the well-preserved primary intergranular porosity. Distribution of porosity is partly limited by compaction and cementation processes (Fig. 5). Aeolian sands were most likely characterized by a well-developed pore network after sedimentation. Good grain sorting had a decisive role in shaping the original high porosity. Compaction and cementation by early carbonate cements caused fragmentation of the primary pore network. As a result, diagenetic processes caused the transfer of dominants from class VI pore volume to a lower class ( $V$ and IV). The presence of the lowest pore volume classes (I and II) is connected with the presence of clay minerals (illite and kaolinite) in pores, which are authigenic minerals and formed very fine, dispersed microporosity (Figs. 5 and 6). Such microporosity may also be formed by grain dissolution, but no dissolved grains were observed in this group of sandstones. Hence, compaction and cementation by carbonate and clay minerals formed the current values of porosity. In addition to the primary characteristics of the sediment, it is observed that the distribution of porosity is characterized by clear anisotropy in the 3D visualisation (Fig. 6). It is the result of the presence of cross bedding and the occurrence of interlayered fine- and medium-grained sandstones. Medium-grained sandstones are characterized by a higher class $\mathrm{VI}$ pore volume than fine-grained sandstones.

A2 sandstones. A2 sandstones are characterized by a dominance of intergranular porosity (up to $5 \%$ ), similar to A1 sandstones. However, the pores are much smaller and the pore distribution is reduced by intense compaction of poorly sorted grains and the occurrence of high volume of cements (Fig. 5). The plots of pore volume class distribution are characterized by the lack of class $\mathrm{VI}$ and the dominance of class III or IV (Fig. 6). It is likely that class VI never formed as a result of poor sorting. If class VI was created, it was quickly reduced to the lower classes as a result of compaction. In addition, primary porosity was reduced by clay and carbonate cementation. A higher portion of class I in A2 sandstones indicates a higher content of clay minerals in the pore space. Depending on the sorting of grains and the intensity of compaction and cementation processes, the dominant moved from class VI to classes III-IV, relative to A1 sandstone (Fig. 6). The 3D visualisation shows clear anisotropy in the distribution of porosity (Fig. 6) associated with the occurrence of cross bedding, as observed in A1 sandstones.

F1 sandstones. F1 sandstones are characterized by the occurrence of primary, intergranular and secondary porosity. Secondary porosity is associated with the dissolution of feldspar grains and volcanic and clastic lithoclasts (Fig. 5). The size 
of intergranular pores reaches over $100 \mu \mathrm{m}$ and they are partially connected with each other. Secondary pores are smaller $(<5 \mu \mathrm{m})$ and they are randomly distributed in the sample. Total porosity reaches $3 \%$. The plots of pore volume class distribution are characterized by a lack of class $\mathrm{VI}$ and dominance of class III or IV. The plots for F1 sandstones are very similar to those for A2 sandstones (Fig. 6). F1 sandstones are poorly sorted, with a small share of matrix in the intergranular pore space. The lack of class VI pore volume may be caused by poorer grain sorting of F1 sandstones and a much less developed pore network at the stage of sedimentation. Poorer grain sorting also favoured the intensity of compaction processes, which resulted in further degradation of the pore network. In addition, carbonate cementation minerals significantly reduced the primary porosity (Fig. 5). Over $10 \%$ of the pores are related to class I pore volume, which is linked to the secondary porosity as a result of the dissolution of unstable grains (volcanic and clastic lithoclasts), and has created small, isolated pores. The uneven distribution of porosity is clear in the 3D visualisation, which is associated with intense compaction and the presence of carbonate cements (Fig. 6).

F2 sandstones. F2 sandstones are characterized by the dominance of very fine pores of $<5 \mu \mathrm{m}$ (Fig. 5). The sandstones are poorly sorted, with a high proportion of matrix in the pore space. Grains are closely packed and the intergranular space is filled by carbonate cements. Porosity does not exceed $1 \%$. The plots of pore volume class distribution are characterized by the lack of class $\mathrm{VI}$ pore volume and distinctive presence of class I pore volume (Fig. 6). The dominant class I pore volume indicates microporosity, which was confirmed by microscopic observations. We have observed secondary porosity in the thin sections (Fig. 5) related to feldspar grain and lithoclast dissolution and the presence of clay minerals-residuum after grain dissolution. The $3 \mathrm{D}$ visualisation shows clear regular anisotropy in the distribution of porosity associated with the occurrence of zones of strong compaction and carbonate cements in the pore space.

\section{DISCUSSION}

Upper Rotliegend sandstones on the northern margin of the Wolsztyn Ridge are characterized by much lower porosities compared to aeolian sandstones in the central part of the Poznań Basin and are linked with the occurrence of fluvial and alluvial deposits near the Wolsztyn Ridge (Buniak et al., 2009). Aeolian sandstones are potentially the best reservoir rock among the clastic rocks due to their initial textural features, the most important of which is the good grain sorting. However, only the A1 sandstones have high porosity (up to 10\%) in the study area, due to good grain sorting, minor compaction and low content of intergranular cement. Sorting of the A2 sandstones is much poorer, the grains are closely packed, and there is a high volume of carbonate and clay cements in the pore spaces; as a result, porosity of the A2 sandstones is less than half that of the A1 sandstones. The fluvial F1 sandstones are similar to the A2 sandstones, despite their different origins, and may in fact represent fluvial sands which were redeposited by aeolian processes during dry periods. Similarly, some aeolian sands may have been redeposited by fluvial transport during wet periods (Kiersnowski et al., 2010b; Kiersnowski, 2013; Poszytek, 2014), and some fluvial and aeolian sandstones may therefore have similar lithologies and porosity distributions. By contrast, F2 sandstones are characterized by a higher matrix content and poorer grain sorting and, as a result, the porosity of these sandstones is very low.
Carbonate cementation is an important process for porosity reduction in the studied samples. Origins of carbonate cements in sandstones can be different depending on the sedimentary environments and diagenetic history. Carbonate cementation in fluvial sandstones is often early and strongly reduces porosity (Maliszewska and Kuberska, 1996; Kuberska, 2004; Rusek et al., 2005), but carbonate cementation in aeolian sandstones can be both early and late-stage.

Early carbonate cements may have been formed as a result of the infiltration of marine waters from overlying Zechstein carbonates (e.g., Buniak et al., 1999, 2009; Kiersnowski et al., 2010b; Poszytek, 2014). This may have occurred in the uppermost Rotliegend sandstones, where permeable aeolian sandstones are overlain by Zechstein deposits; the zone of cementation may be up to tens of metres thick (Poszytek, 2014).

Carbonate cements also occur in aeolian sandstones below the infiltration zone and are probably late-stage cements associated with the fluids migration trough gaps and fissures developed in fault zones (Kiersnowski et al., 2010a). The studied samples have not been examined for the age of carbonate cements (for example by stable isotope studies). Low content of carbonate cements in aeolian sandstones and the occurrence of low-permeability sandstones in the topmost part of the profiles in this area indicate that this cement did not originate from the infiltration of Zechstein water. It could be an early cement, but the source of water was rather a fluvial environment. Both fluvial and aeolian sandstones could be cemented by late carbonate cements in relation to many dislocations in the study area.

\section{CONCLUSIONS}

Our results indicate that the reservoir rock in the studied lithological traps is clearly subdivided into zones of good porosity ( $\mathrm{A} 1$ sandstones), low porosity ( $\mathrm{A} 2$ and $\mathrm{F} 1$ sandstones), and very low porosity (F2 sandstones) (Fig. 7). Different types of sandstones alternate in the profiles, which are reflected in the seismic images as homogenized zones of relatively low porosity. This causes great difficulty in identifying the range of porous and permeable sandstones within the traps on the northern slope of the Wolsztyn Ridge (Kwolek et al., 2004).

All types of sandstones were subjected to the same processes, but the processes were of different intensity. It should be noted that the intensity of diagenetic processes was determined by the sedimentary environment (especially sorting). A1 sandstones are the best sorted, therefore the compaction effect is the smallest compared to other types of sandstones. Early cementation by carbonate cement is also minor; therefore A1 type porosity is the most favourable. The other types of sandstones are characterized by the worst sorting, greater effect of compaction, and higher content of carbonate cements, therefore their porosity is lower.

The MCT results can be used to distinguish diverse pore shape classes which can be interpreted as the results of primary (sedimentary) and secondary (diagenetic) processes (Fig. 8). The presence of class $\mathrm{VI}$ of pore volume (A1 sandstones) indicates the existence of well-preserved primary porosity, which is due to good sorting. The dominance of class IV of pore volume (A2 and F1 sandstones) indicates poorer sorting of grains and more intensified compaction (Fig. 8). A high contribution of class I and II pore volume (F1 and F2 sandstones) is associated with the presence of very fine porosity, which is the result of dissolution of the grains and the presence of clay minerals in the pore space. Poor sorted F2 sandstones contain a huge amount of volcanic and clastic lithoclasts from erosion of the Wolsztyn 


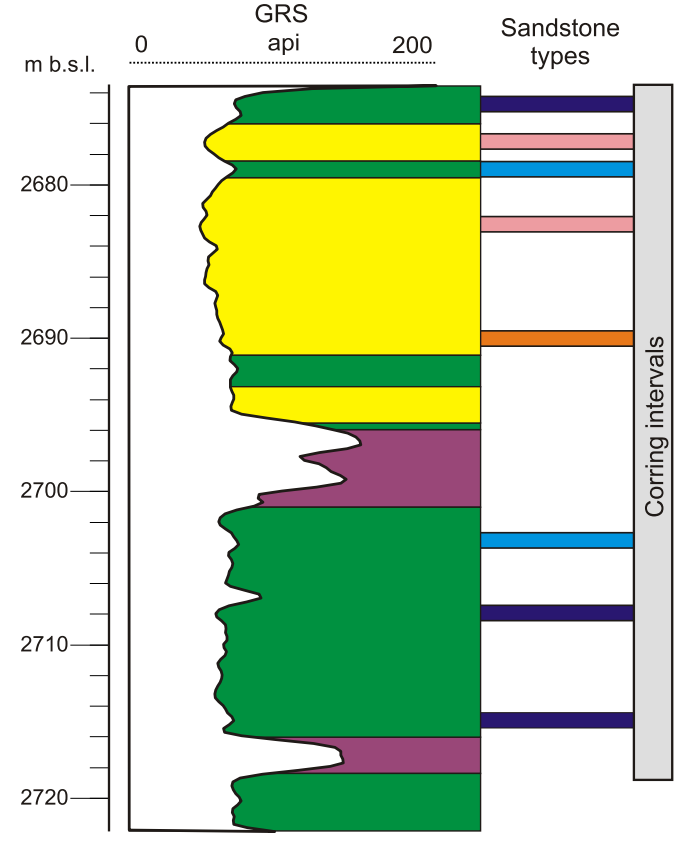

Sedimentary environments

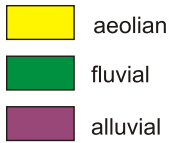

Sandstones types

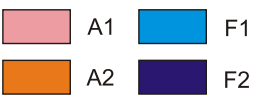

Fig. 7. Upper Rotliegend lithofacies in the Cicha Góra 9 borehole with sandstone types within the top part of the Upper Rotliegend

Ridge. Dissolution of these lithoclasts resulted in an increase of the amount of clay minerals in the matrix of F2 sandstones.

Pore systems created from the MCT results can be used also for numerical modelling. It is important that modelling results should be compared with other methods, especially mercury porosimetry. Hg-Cap-Curve can supplement the data with a range of values smaller than the MCT resolution.

Sedimentary conditions (determining the grain sorting and mineral composition of the rock fabric) and diagenetic processes (compaction, cementation and grain dissolution) have crucial influence on the sandstone porosity. These factors play a decisive role in the creation of sandstone porosity regardless of the origin and age of the sandstone. Hence, the model presented in Figure 8 can be applied to sandstones of different origins and ages. It describes sandstone porosity depending on their lithological and textural features, and diagenetic processes.

\section{Dissolution of grains}

\section{Grain sorting}

\section{Compaction and cementation}

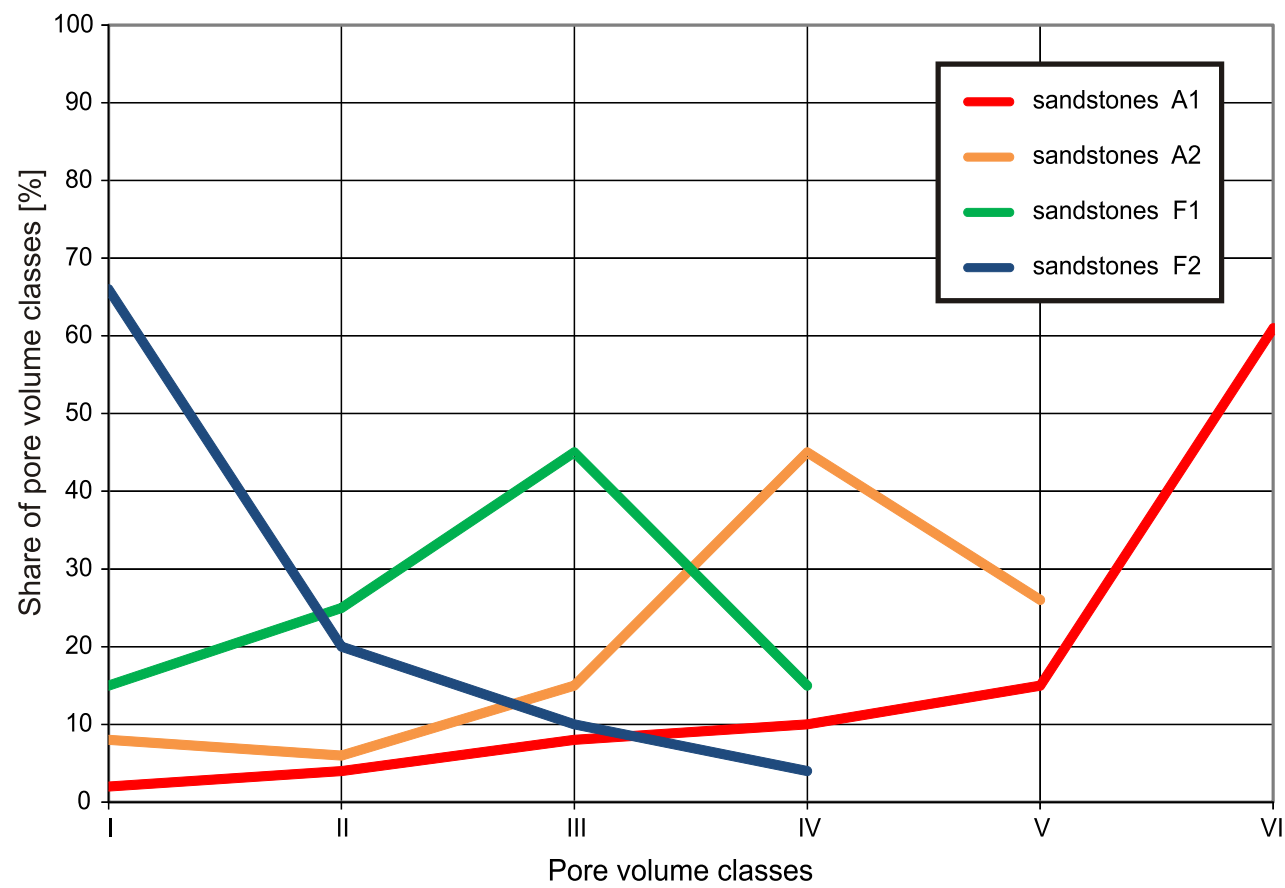

Fig. 8. Model of pore volume class distribution in aeolian and fluvial sandstones 
Acknowledgements. The authors would like to thank Prof. R. Gaupp, Prof. T. Peryt, Dr. M. Kuberska, H. Kiersnowski and Prof. R. Sałaciński for the opportunity to discuss the results of our study. Polskie Górnictwo Naftowe i Gazownictwo S.A. has kindly provided geological information. The authors would like to thank Dr. A. Żylińska for language corrections.

\section{REFERENCES}

Agbogun, H.M.D., Tom, A., Al-Hussein, E.M.A., 2013. Three dimensional imaging of porosity and tracer concentration distributions in a dolostone sample during diffusion experiments using X-ray micro-CT. Journal of Contaminant Hydrology, 145: 44-53.

Buniak, A., Mikołajewski, Z., Protas, A., 1999. Depositional environment and petrology of Rotliegend deposits from the Unisław-Wałdowo Królewskie region (in Polish with English summary). Geologos, 4: 5-27.

Buniak, A., Kuberska, M., Kiersnowski, H., 2009. Petrographical-petrophysical characteristics of the Rotliegend eolian sandstones of the Siekierki-Winna Góra Zone (the Poznań region) in the aspect of search for gas trapped in deposits (in Polish with English summary). Przegląd Geologiczny, 57: 328-334.

Cnudde, V., Cwirzen, A., Masschaele, B., Jacobs, P.J.S., 2009 Porosity and microstructure characterization of building stones and concretes. Engineering Geology, 103: 76-83.

Couves, C., Roberts, S., Racey, A., Troth, I., Best, A., 2016. Use of X-ray computed tomography to quantify the petrophysical properties of volcanic rocks: a case study from Teneriffe, Canary Islands. Journal of Petroleum Geology, 39: 79-94.

Dadlez, R., 2006. The Polish Basin - relationship between the crystalline, consolidated and sedimentary crust. Geological Quarterly, 50 (1): 43-58.

Dohnalik, M., Zalewska, J., Kaczmarczyk, J., 2010. Sandstone sample classification, using high resolution CT method. International Symposium of the Society of Core Analysts held in Halifax, Nova Scotia, Canada, 4-7 October, www.scaweb.org

Doornenbal, J.C., Stevenson, A.G., eds., 2010. Petroleum Geological Atlas of the Southern Permian Basin Area. EAGE Publications b.v. (Houten).

Dyjaczyński, K., Peryt, T.M., 2014. Controls on basal Zechstein (Wuchiapingian) evaporite deposition in SW Poland. Geological Quarterly, 58 (3): 485-502.

Fusi, N., Martinez-Martinez, J., 2013. Mercury porosimetry as a tool for improving quality of micro-CT images in low porosity carbonate rocks. Engineering Geology, 166: 272-282.

Geisler, M., Breitkreuz, C., Kiersnowski, H., 2008. Late Paleozoic volcanism in the central part of the Southern Permian Basin (NE Germany, W Poland): facies distribution and volcano-topographic hiati. International Journal of Earth Sciences, 97: 973-989.

Glennie, K.W., 1990. Outline of North Sea history and structural framework. In: Introduction to the Petroleum Geology of the North Sea (ed. K.W. Glennie): 34-77. Blackwell Science, London.

Gregosiewicz, Z., Protas, A., 1997. Facies, diagenesis and reservoir properties of the Rotliegend sandstones in the area of Radlin gas field (in Polish with English summary). Nafta-Gaz, 57: $375-387$.

Jarzyna, J., Puskarczyk, E., Bała, M., Papiernik, B., 2009. Variability of the Rotliegend sandstones in the Polish part of the Southern Permian Basin - permeability and porosity relationships. Annales Societatis Geologorum Poloniae, 79: 13-26.

Jerzykiewicz, T., Kijewski, P., Mroczkowski, J., Teisseyre, A.K., 1976. Origin of the Weissliegendes deposits in the Fore-Sudetic Monocline (in Polish with English summary). Geologia Sudetica, 11: $57-100$.

Karnkowski, P., 1999. Oil and Gas Deposits in Poland. Wyd. Geos, Kraków.

Karnkowski, P.H., 1985. Conditions of origin of gas deposits in the Wielkopolska region (in Polish with English summary). Geological Quarterly, 29 (2): 355-368.
Karnkowski, P.H., 1986. The nature of Zechstein transgression versus origin of Weissliegendes in the Wielkopolska area (northern Fore-Sudetic Monocline, western Poland (in Polish with English summary). Geologia Sudetica, 21: 101-122.

Karnkowski, P.H., 1987. Facies analysis of Wielkopolska subgroup (Upper Rotliegend) in the northern part of the Fore-Sudetic Monocline (in Polish with English summary). Przegląd Geologiczny, 35: 187-192.

Karnkowski, P.H., 1994. Rotliegend lithostratigraphy in the central part of the Polish Permian Basin. Geological Quarterly, 38 (1): $27-42$

Karnkowski, P.H., 1999. Origin and evolution of the Polish Rotliegend Basin. Polish Geological Institute Special Papers, 3: 1-93.

Karnkowski, P.H., 2007. Permian Basin as a main exploration target in Poland (in Polish with English summary). Przegląd Geologiczny, 55: 1003-1015.

Ketcham, R.A., Carlson, W.D., 2001. Acquisition, optimization and interpretation of X-ray computed tomographic imagery: applications to the geosciences. Computers and Geosciences, 27: 381-400.

Kiersnowski, H., 1997. Depositional development of the Polish Upper Rotliegend Basin and evolution of its sediment source areas. Geological Quarterly, 41 (4): 433-456.

Kiersnowski, H., 2013. Late Permian aeolian sand seas from the Polish Upper Rotliegend Basin in the context of palaeoclimatic periodicity. Geological Society Special Publications, 376: 431-456.

Kiersnowski, H., Buniak, A., 2006. Evolution of the Rotliegend Basin of northwestern Poland. Geological Quarterly, 50 (1): 119-137.

Kiersnowski, H., Buniak, A., Kuberska, M., Srokowska-Okońska, A., 2010a. Tight gas accumulations in Rotliegend sandstones of Poland (in Polish with English summary). Przegląd Geologiczny, 58: 335-346.

Kiersnowski, H., Peryt, T.M., Buniak, A., Mikołajewski, Z., 2010b. From the intra-desert ridges to the marine carbonate island chain: middle to late Permian (Upper Rotliegend-Lower Zechstein) of the Wolsztyn-Pogorzela High, west Poland. Geological Journal, 45: 319-335.

Kuberska, M., 2004. Diagenesis of the Rotliegend rocks in the Szczecinek-Bydgoszcz area (Western Pomerania) (in Polish with English summary). Biuletyn Państwowego Instytutu Geologicznego, 411: 87-168.

Kwolek, K., Solarski, T., Buniak A., 2004. Exploration of lithologic traps in the Rotliegendes on the NE slope of Wolsztyn High. 66th EAGE Conference and Exhibition, 7-10 June 2004, Paris, France. EarthDoc P242.

Lamarche, J., Scheck-Wenderoth, M., 2005. 3D structural model of the Polish Basin. Tectonophysics, 397: 73-91.

Maliszewska, A., Kuberska, M., 1996. Cementation of Rotliegend sandstones and their porosity and permeability (in Polish with English summary). Nafta-Gaz, 9: 365-373.

Mazur, S., Kurowski, L., Aleksandrowski, P., Żelaźniewicz, A., 2003. Variscan foreland fold-thrust belt of Wielkopolska (W Poland): new structural and sedimentological data. Geolines, 16: 71.

Mazur, S., Aleksandrowski, P., Kryza, R., Oberc-Dziedzic, T., 2006. The Variscan Orogen in Poland. Geological Quarterly, 50 (1): 89-118. 
Michalik, M., 2001. Diagenesis of the Weissliegend sandstones in the south-west margin of the Polish Rotliegend Basin. Prace Mineralogiczne, 91: 3-171.

Muszyński, M., Rydzewska, W., 1986. Dlagenetic changes and their influence on reservoir properties of Saxonian rocks in central part of the Fore-Sudetic Monocline (in Polish with English summary). Przegląd Geologiczny, 34: 509-514.

Nemec, W., Porębski, S.J., 1977. Weissliegendes sandstones: a transition from fluvial-eolian to shallow-marine sedimentation (Lower Permian of the Fore-Sudetic Monocline). 1. Sedimentary structures and textural differentiation. Rocznik Polskiego Towarzystwa Geologicznego, 47: 387-418.

Nikishin, A.M., Ziegler, P.A., Abbott, D., Brunet, M.F., Cloetingh, S., 2002. Permo-Triassic intraplate magmatism and rifting in Eurasia: implications for mantle plumes and mantle dynamics. Tectonophysics, 351: 3-39.

Papiernik, B., Górecki, W., Pasternacki, A., 2010. Preliminary results of 3D modeling of petrophysical parameters for tight gas prospecting in the Polish Rotliegend Basin (in Polish with English summary). Przegląd Geologiczny, 58: 352-364.

Peryt, D., Peryt, T.M., Raczyński, P., Chłódek, K., 2012 Foraminiferal colonization related to the Zechstein (Lopingian) transgression in the western part of the Wolsztyn Palaeo-Ridge area, Western Poland. Geological Quarterly, 56 (3): 529-546.

Peryt, T.M., 1976. Thuringian (Upper Permian) marine ingression in the area of Fore-Sudetic monocline (Poland) (in Polish with English summary). Rocznik Polskiego Towarzystwa Geologicznego, 46: 455-465.

Pettijohn, F.J., Potter, P.E., Siever, R., 1972. Sand and Sandstones. Springer, New York.

Pokorski, J., Kiersnowski, H., 1999. Wybrane elementy ewolucji basenu czerwonego spagowca na podstawie analizy tektonicznej i litofacjalnej (in Polish). Przegląd Geologiczny, 47: 464.

Poprawa, P., Kiersnowski, H., 2008. Potential for shale gas and tight gas exploration in Poland (in Polish with English summary) Biuletyn Państwowego Instytutu Geologicznego, 429: 145-152.

Poprawa, P., Kiersnowski, H., 2010. Tight gas accumulations in Rotliegend sandstones of Poland (in Polish with English summary). Biuletyn Państwowego Instytutu Geologicznego, 439 : 173-180.

Poszytek, A., 2014. Reservoir properties of the Upper Rotliegend and the Weissliegend sandstones (Permian) in the Zielona Góra Basin (western Poland). Geological Quarterly, 58 (1): 193-206.

Rochewicz, A., 1980. Wpływ procesów illityzacji i chlorytyzacji na własności kolektorskie piaskowców czerwonego spagowca SW Polski (in Polish). Archiwum Mineralogiczne, 36: 55-61.
Rusek, M., Buniak, A., Solarska, A., Kowalczak, M., Gaupp, R., 2005. Piaskowce czerwonego spagowca i ich diageneza na obszarze wału pomorskiego (złoże Ciechnowo) (in Polish). Przegląd Geologiczny, 53: 340-341.

Stock, S.R., 2008. Micro Computed Tomography: Methodology and Applications. CRC Press, Boca Raton, Florida, USA.

Such, P., 1996. Physical model of the filtration in the Rotliegend basin (in Polish with English summary). Prace Instytutu Nafty i Gazu, 88.

Such, P., Maliszewska, A., Leśniak, G., 2000. The Rotliegend filtration properties and facies (in Polish with English summary). Prace Instytutu Nafty i Gazu, 103: 5-49.

Such, P., Leśniak, G., Słota, M., 2010. Quantitative porosity and permeability characterization of potential Rotliegend tight gas reservoirs (in Polish with English summary). Przegląd Geologiczny, 58: 347-351.

Svitelman, V., Dinariev, O., 2013. Geostatistical approach to the anisotropy analysis of 3D rock microtomographic models, Computers and Geosciences, 57: 116-123.

Szwarc, R., Kiersnowski, H., 1999. Rozwój sedymentacji osadów czerwonego spagowca w SE części polskiego basenu permskiego (in Polish). Przegląd Geologiczny, 47: 469-470.

Van Geet, M., Swennen, R., Wevers, M., 2001. Towards 3-D petrography: application of microfocus computer tomography in geological science. Computers and Geosciences, 27: 1091-1099.

Wagner, R., Peryt, T.M., 1997. Possibility of sequence stratigraphic subdivision of the Zechstein in the Polish Basin. Geological Quarterly, 41 (4): 457-474.

Weihe, T., 1997. Sedimentologie und Fazies des Rotliegenden (unteres Perm) nördlich des Wolsztyn-Hochs, Westpolen, im Spiegel der Beckenentwicklung. Clausthaler Geowissenschaftliche Dissertationen, 51: 1-142.

Wolnowski, T., 2004. Prognoza zasobności czerwonego spagowca w basenie permskim niżu polskiego w świetle nowych technik poszukiwawczych (in Polish). Konferencja Naukowo-Techniczna „Basen permski Niżu Polskiego - czerwony spagowiec, budowa i potencjał zasobowy". Piła 23 IV 2004: 17-30.

Zalewska, J., Dohnalik, M., 2011. Comparison of rock pore space based on X-ray computed microtomography (micro-CT) and nuclear magnetic resonance (NMR) data. Part III. Nafta-Gaz, 67: 702-713.

Zapalski, M.K., Dohnalik, M., 2013. Blastogeny in tabulate corals: case studies using X-ray microtomography. Lethaia, 46: 223-231.

Ziegler, P.A., 1990. Geological Atlas of Western and Central Europe. Shell Int. Petr. Maa. B.V. 